\title{
In situ monitoring of the genotoxic effects in the vicinity of a petrochemical plant with the Tradescantia micronucleus (Trad-MCN) and with pollen abortion test
}

\author{
Miroslav Mišík1, Karol Mičieta², Martina Solenská2, Nataša Markuskováa \\ Katarína Mišíková ${ }^{2}$ and Siegfried Knasmüller*1
}

\author{
Address: ${ }^{1}$ Institute of Cancer Research, Medical University of Vienna, Austria and ${ }^{2}$ Department of Botany, Faculty of Natural Sciences, Comenius \\ University Bratislava, Slovakia \\ Email: Siegfried Knasmüller* - siegfried.knasmueller@meduniwien.ac.at \\ * Corresponding author
}

from 13th Scientific Symposium of the Austrian Pharmacological Society (APHAR). Joint Meeting with the Austrian Society of Toxicology (ASTOX) and the Hungarian Society for Experimental and Clinical Pharmacology (MFT)

Vienna, Austria. 22-24 November 2007

Published: 14 November 2007

BMC Pharmacology 2007, 7(Suppl 2):A53 doi:10.1 I86/I47|-22I0-7-S2-A53

This abstract is available from: http://www.biomedcentral.com/I47I-22/0/7/S2/A53

C 2007 Mišík et al; licensee BioMed Central Ltd.

The aim of this study was to monitor the genotoxic effects of polluted air in Bratislava (Slovakia). In situ monitoring was carried out at a location polluted with emissions from a city incinerator and of a petrochemical plant. The Tradescantia micronucleus (Trad-MCN) test and pollen abortion assays with wild life plants (Chelidonium majus, Clematis vitalba, Cichorium intybus, Linaria vulgaris) were used in this study. The experiments were carried out during two sampling periods i.e. 1997-2000 and 2003-2006. Compared to the effects seen in Tradescantia plants exposed in a rural area with low pollution levels, the MCN frequencies in pollen tetrads were significantly higher in specimens from the urban site during the first period whereas no significant differences were found during the second sampling period. The results of the pollen abortion assays showed a similar pattern as that observed in the TradMCN bioassays, i.e. pronounced effects were only seen between 1997 and 2000. The differences of the results obtained in the two sampling periods can be explained by reduction of the pollution of the urban air due to new production technologies and installation of filter systems which led to a substantial improvement of air quality parameters such as particulate matter, organic volatiles and $\mathrm{SO}_{2}$ emissions. These results confirm the sensitivity of the Tradescantia MCN test and of pollen abortion assays for the detection of air pollution and that both biomoni- toring models reflect improvement of air quality parameters. 